\author{
Asian Economic and Financial Review \\ $\operatorname{ISSN}(e): \quad 2222-6737$ \\ $\operatorname{ISSN}(p): \quad 2305-2147$ \\ DOI: 10.18488/journal.aefr.2020.109.1051.1061 \\ Vol. 10, No. 9, 1051-1061. \\ (C) 2020 AESS Publications. All Rights Reserved. \\ URL: www.aessweb.com \\ check for
updates
}

\title{
THE CONTRIBUTION OF FINANCIAL INCLUSION IN REDUCING \\ POVERTY AND INCOME INEQUALITY IN DEVELOPING COUNTRIES
}

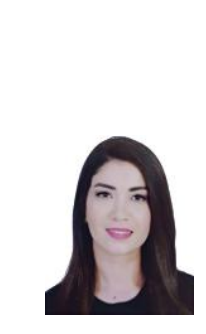

Ichraf Ouechtati

\author{
Faculty of Legal, Economic and Management Sciences of Jendouba, \\ University of Jendouba, Tunisia. \\ Email:ouechtati.chraf@yahoo.fr
}

Article History

Received: 9 July 2020

Revised: 19 August 2020 Accepted: 23 September 2020

Published: 5 October 2020

\section{Keywords}

Financial inclusion

Banking services

Financial access

Poverty

Income inequality

Dynamic panel estimation.

JEL Classification: C33; G20; G21; O 11; O 15 .

\begin{abstract}
$\operatorname{ABSTRACT}$
This study employed three different dynamic panel data estimators to empirically examine the effect of financial inclusion on poverty and income inequality for a sample of 53 developing countries between 2004 and 2017. The findings revealed a negative relationship between financial inclusion and poverty; within which availability of credit and access to deposit accounts at commercial banks tend to significantly alleviate poverty. These results support the idea that financial access, as well as financial development, contribute to reducing poverty by increasing the money supply or credit and improving the welfare of the poor. Furthermore, it was concluded that a high bank penetration rate and credit facilitate access to financial services for the poor and reduce income inequality. This result was corroborated by the bias-corrected fixed effects estimator at significance levels of $5 \%$ and $1 \%$, respectively. Those proxy variables for financial inclusion that exert no significant effects could be explained by weak financial institutional structures, plus the need to incorporate elements of financial inclusion into a stronger framework, which would exert an effective impact on poverty and income inequality.
\end{abstract}

Contribution/Originality: This paper contributes to the existing literature by employing three dynamic panel data estimators-bias-corrected fixed effects, difference GMM, and system GMM - to assess the effects of financial inclusion on income inequality and poverty and deal with endogeneity issues.

\section{INTRODUCTION}

Since the late 1990s, financial inclusion has attracted growing attention owing to evidence of its significant effects on improving economic development, reducing poverty (Boukhatem, 2016) and financial stability (Han \& Melecky, 2013).

Financial inclusion is defined as "the availability of a supply of reasonable quality financial services at reasonable costs" (Claessens, 2006), meaning that access to financial services involves not only benefits (e.g., savings and interest, or credit) but also costs (e.g., bank fees and commissions). However, it is also defined as "the process for ensuring access to financial services and timely and adequate credit where needed by vulnerable groups such as weaker sections and low income groups" (Rangarajan, 2008) from which it can be inferred that financial inclusion primarily targets vulnerable people in society, such as the poor, with the aim of reducing inequalities. 
Since the concept of financial inclusion has emerged, an increasing number of studies on its relationship with poverty and income inequality have been conducted. Today, the World Bank's ultimate goal is to reduce global poverty, since it estimated that $10 \%$ of the world's population earned less than 1.90USD per day in 2015, compared with $11 \%$ in 2013 and $36 \%$ in 1990. It considers this reduction rate to be insufficient for achieving its target of ending extreme poverty by 2030 (World Bank, 2019).

Hence, financial inclusion is becoming one solution to reducing poverty and income inequality and stimulating economic growth and employment. In this context, the current study aims to investigate the impact of financial inclusion on income inequality and poverty in developing economies; thus, it contributes to the existing body of literature not only on the relationship between financial inclusion and income inequality and poverty but also developing countries. Consequently, a dynamic panel data model of 53 countries for the period 2004-2017 was constructed and analyzed with three dynamic panel estimators-bias-corrected fixed effects (C.FE), difference (Diff) generalized method of moments (GMM), and system (Sys) GMM-which means endogeneity is controlled correctly.

In general, earlier empirical studies that have also examined the effect of financial inclusion on poverty and income inequality and employed dynamic panel data models, have likewise used fixed effects or estimation (Agyemang-Badu, Agyei, \& Kwaku Duah, 2018; Neaime \& Gaysset, 2018; Omar \& Inaba, 2020). Unfortunately, both estimation methods have been criticized in the econometric literature. First, fixed effects are biased in short panels, due to the correlation between the lagged dependent variable and the error term. GMM is the simplest, and most efficient, solution to this endogeneity issue, being based on several instrumental variables; however, the risk of bias still exists with weak instrumental variables, particularly in the case of overidentification. To retain the advantages of these estimation methods while taking account of their caveats, the estimation methods in this study are modified to produce more robust results: the aforementioned C.FE, Diff, and Sys estimators. The final objective is to seek significant and robust interaction between financial inclusion and poverty on the one hand and financial inclusion and income inequality on the other.

This paper is structured as follows: Section 2 presents a literature review on financial inclusion; Section 3 describes the econometric model and data; Section 4 discusses the empirical results and analysis; and Section 5 offers conclusions from the findings.

\section{LITERATURE REVIEW}

Financial inclusion had long been neglected by scholars, until the 1990s, when studies proliferated alongside financial exclusion, which prevent access to financial services by some social groups and individuals (Collard, 2010; Leyshon \& Thrift, 1995; Sinclair, 2001).

Studies on the concept of financial inclusion started to develop further in the early 2000 , becoming more focused on the determinants of financial inclusion: the characteristics of the financially excluded classes and the relationship between financial inclusion and economic growth and development.

\subsection{Determinants of Financial Inclusion}

The main determinants of financial inclusion have been identified as purchasing power, educational level, age, gender, and marital status. Zins and Weill (2016) study in Africa found that being an older, wealthier, bettereducated man was more likely to be financially included. Meanwhile, on a global scale, Allen, Demirguc-Kunt, Klapper, and Peria (2016) discovered that older, wealthier, better-educated, employed, urban-dwelling people, whether married or separated, were more likely to hold accounts at formal financial institutions; they also highlighted that formal borrowing increased among older, wealthier, better-educated, married men. Further primary determinants were revealed by other studies to be aspirations, financial literacy, and gender (Kostov, Arun, \& Annim, 2015). For instance, in a study of 98 countries, Demirgüç-Kunt, Klapper, and Singer (2013) revealed a 
large gender gap in account-holders and formal credit and savings, with men being much more financially integrated than women. In addition, Kim (2016) reported that individuals were excluded from formal financial services due to ineligibility, unavailability, and financial illiteracy.

Features of the banking sector are also key factors. Both Demirgüc,-Kunt and Klapper (2012b) and Allen et al. (2016) showed that high costs associated with opening and operating bank accounts, physical distance, and lack of appropriate documentation to fulfill the identity verification requirement often prevented access to financial services, and thus formal financial inclusion.

In addition, there are studies that have identified the role of economic and socioeconomic factors in financial inclusion. Evans and Adeoye (2016) found that GDP per capita, money supply, adult literacy rate, internet access, and Islamic banking were the main determinants of financial inclusion in Africa. Furthermore, Rojas-Suarez and Amado (2014) reported that socioeconomic factors, such as income inequality, as well as macroeconomic weaknesses, such as inflation volatility, explained the financial inclusion gap between countries on a global scale. These authors, as well as Allen et al. (2016) have also emphasized the role played by not only financial institutions but also the rule of law: high-quality institutions, efficient enforcement of legal regulations, rigorous application of contracts, and political stability support greater financial inclusion.

\subsection{Financial Inclusion and Economic Growth and Development}

Based on previous studies, Omar and Inaba (2020) have analyzed the impact of financial inclusion on reducing poverty and income inequality, plus the micro- and macroeconomic conditions under which that effect is achieved. Fixed-effects estimation revealed that extending financial inclusion dramatically reduced poverty and income inequality in developing countries, with the interaction between financial inclusion with GDP growth and secondary school enrollment exerting a statistically significant effect on poverty and the interaction between financial inclusion with GDP growth and the rule of law a statistically significant effect on income inequality. Their findings demonstrated that the effectiveness of financial inclusion depends on different factors, scenarios, and economic conditions.

These results supported those of Agyemang-Badu et al. (2018) who found that financial inclusion is inversely related to both poverty and income inequality in Africa, and thus recommended implementing policies and programs that strengthen formal financial inclusion of the poor. Likewise, in sub-Saharan Africa, Jabir, Mensah, and Gyeke-Dako (2017) found that financial inclusion dramatically reduced poverty among low-income households in 35 countries by providing net wealth and greater social benefits. Park and Mercado (2015) also found that financial inclusion significantly reduced income inequality and poverty in developing Asian countries, and suggested that action was needed to address the growing income inequalities and promote poverty reduction in the region. Finally, Kim (2016) not only confirmed financial inclusion reduced income inequality but also turned the inverse relationship between economic growth and income inequality into a positive one.

Previously, Honohan (2004) and Demirguc-Kunt and Klapper (2012) had revealed that although financial inclusion accelerates the GDP per capita growth rate, it cannot assist the poor. Similarly, Chauvet and Jacolin (2017) discovered that financial inclusion, defined as the distribution of financial services across firms, positively affects business growth in emerging and developing countries, particularly when banks are more competitive, although only at high levels of financial inclusion. Moreover, Kim, Yu, and Hassan (2018) reported financial inclusion exerting a positive effect on economic growth in the member states of the Organization of Islamic Cooperation. These studies reinforced the viewpoint expressed earlier by Cumming, Johan, and Zhang (2014) who emphasized the importance of access to finance in encouraging firms to take risks and invest more, resulting in an active and positive contribution to economic growth. With regard to the Middle East and North Africa (MENA) region, Pearce (2011) stated that integrating the "unbanked" population into the financial system was a major concern for policymakers in the region. He asserted that exclusion prevented poor people building up any savings 
as a buffer against potential risks and for investment in income-generating projects. Moreover, the availability of banking agencies and microfinance in some MENA countries had failed to reduce financial exclusion, income inequality, and poverty; thus, despite their increased profitability and efficiency, banks were still not reaching society's underprivileged (Pearce, 2011). Sarma and Pais (2011) revealed a close relationship between the index of financial inclusion (IFI) and the Human Development Index (HDI): both income and physical infrastructure for connectivity and information were significantly associated with financial inclusion. Rizwan and Bruneau (2019) further studied the role of information and communication technologies (ICT) in extending financial inclusion and reducing poverty and income inequality using a sample of 62 countries over the period from 2001 to 2012. Their results showed a positive association between ICT and financial inclusion and negative with poverty and income inequality, accelerating economic growth. They therefore recommended promoting digital finance to encourage financial inclusion. Another impact of financial inclusion was explored by Le, Chuc, and Taghizadeh-Hesary (2019) in terms of financial efficiency and sustainability across 31 Asian countries between 2004 and 2016. Principal component analysis showed varying effects from one country to another, with no clear trend, while feasible generalized least squares (FGLS) estimation indicated that increasing financial inclusion exerted a negative impact on financial efficiency and positive on financial sustainability.

Other studies similarly examined the essential role played by financial inclusion in improving well-being: Swamy (2014) demonstrated that the financial inclusion of poor women substantially increased income and improved family well-being in India, which confirmed the work of Brune, Giné, Goldberg, and Yang (2011) in which enabling financial access for poor smallholders in Malawi was important for their well-being.

\section{ECONOMETRIC MODEL AND DATA}

This section describes the data and model used to estimate the effect of financial inclusion on poverty and income inequality. Dynamic panel data for 53 developing economies between 2004 and 2017 was extracted from the World Bank (2019) and the bias-corrected fixed effects, difference GMM, and system GMM estimators were applied. Each has its advantages and disadvantages: While the GMM estimators correct endogeneity problems, the bias-corrected fixed effects estimator, which is constructed with lagged values after the fixed effects are eliminated, accommodates the problem of weak instrumental variables. The following equations are therefore estimated:

$$
\begin{aligned}
& \text { Pov }_{i, t}=\sum_{j=1}^{p} \alpha_{j}, \text { Pov }_{i, t-j}+\beta_{1} \cdot G D P c_{i, t}+\beta_{2}, \text { Expense }_{i, t}+\beta_{3} \cdot \text { Trade }_{i, t}+\beta_{4}, \text { Infl }_{i, t}+\left\{\begin{array}{l}
\beta_{5} A T M_{i, t} \\
\beta_{6} B B C H_{i, t} \\
\beta_{7} B R W_{i, t} \\
\beta_{8} D P T R_{i, t}
\end{array}\right\}+ \\
& v_{i}+\varepsilon_{i t} \\
& G_{i, t}=\sum_{j=1}^{p} \alpha_{j}, G I_{i, t-j}+\beta_{1} \cdot G D P c_{i, t}+\beta_{2} \cdot \text { Expense }_{i, t}+\beta_{3} \cdot \text { Trade }_{i, t}+\beta_{4}, \text { Infl }_{i, t}+\left\{\begin{array}{l}
\beta_{5} \text { ATM }_{i, t} \\
\beta_{6} B R C H_{i, t} \\
\beta_{7} B R W_{i, t} \\
\beta_{8} D P T R_{i, t}
\end{array}\right\}+ \\
& v_{i}+\varepsilon_{i t}
\end{aligned}
$$

Where: $P o v_{i, t}$ denotes the proxy variable for the poverty rate in country $i$ at time $t$, based on the log difference of the percentage of the population below the national poverty line (i.e., poverty headcount ratio); $G D P c_{i_{i}}$ denotes GDP per capita, a proxy variable for economic growth; Expense $e_{i_{z}}$ denotes cash payments for the 
operating activities of providing goods and services by the government, measured as a share of GDP; Trade $e_{i, t}$ denotes the sum of exports and imports of goods and services, measured as for Expense $e_{i_{2} t}$; and $\operatorname{Infl} l_{i_{i} t}$ denotes inflation, measured by the annual growth rate of the GDP implicit deflator. Financial inclusion is denoted by the following four proxy variables:

- $\quad A T M$ denotes account ownership, measured as automated teller machines per 100,000 adults.

- $\quad B R C H$ denotes penetration rate of financial institutions, measured as bank branches per 100,000 adults.

- $\quad B R W$ denotes credit, measured as commercial bank borrowers per 1000 adults.

- $\quad D P T R$, denotes savings, measured as commercial bank deposit accounts per 1000 adults.

The dependent variables are $\operatorname{Pov}_{i, t}$ in Equation 1 the Gini index $\left(G I_{i, t}\right)$, denoting income inequality, in Equation 2; the explanatory variables are the four proxy variables for financial inclusion.

\section{EMPIRICAL RESULTS}

Table 1 summarizes the descriptive statistics for each variable in the model, using log-transformed data. For income inequality $(G I)$ and poverty Pov, the former has the higher mean while the latter has the higher standard deviation. From the four financial inclusion variables, bank penetration rate $(B R C H)$ has the highest mean but lowest standard deviation, with savings $(D P T R)$ having the lowest mean and account ownership $(A T M)$ the highest standard deviation. Finally, of the other three variables, Expense has the lowest mean while Infl has the highest standard deviation.

Table-1. Summary of descriptive statistics for variables.

\begin{tabular}{c|c|c|c|c|c}
\hline Variables & Mean & Median & $\begin{array}{c}\text { Std } \\
\text { Dev }\end{array}$ & Min & Max \\
\hline Pov & 221 & 3.200 & 0.709 & -0.916 & 4.341 \\
\hline GI & 252 & 3.703 & 0.201 & 3.254 & 4.110 \\
\hline ATM & 633 & 2.302 & 1.680 & -4.141 & 4.781 \\
\hline BRCH & 677 & 2.016 & 1.059 & -1.241 & 4.271 \\
\hline BRW & 566 & 4.053 & 1.586 & -0.953 & 6.771 \\
\hline DPTR & 549 & 5.726 & 1.180 & 0.171 & 7.625 \\
\hline GDPC & 597 & 1.213 & 0.975 & -6.187 & 4.092 \\
\hline Expense & 530 & 3.005 & 0.469 & 1.031 & 4.348 \\
\hline Trade & 713 & 4.197 & 0.770 & -1.787 & 5.348 \\
\hline Infl & 692 & 1.702 & 1.048 & -2.769 & 4.558 \\
\hline
\end{tabular}


To evaluate the validity of using lagged variables as instruments in difference and system GMM, two tests were performed: (i) the Arellano-Bond test for second-order serial correlation AR(2); (ii) the Hansen test of overidentifying restrictions.

Adopting the methods followed by Arellano and Bond (1991) and Blundell and Bond (1998) for dynamic panel data, as well as Bun and Kiviet (2003) for bias-corrected fixed effects estimation, the results of financial inclusion (FI) impact on poverty are shown in Table 2.

The results of bias-corrected fixed effects estimation (C.FE; Columns 1, 4, 7, and 10) reveal that FI exerts a negative but insignificant effect on poverty. In contrast, difference (Diff) and system (Sys) GMM estimation show some significantly negative effects of $F I$ on poverty. The most significant negative effects on poverty under Diff and Sys are BRW and DPTR: on average, a $1 \%$ increase in credit tends to alleviate poverty by 0.203 and 0.223 , respectively; while on average, a $1 \%$ increase in savings tends to reduce poverty by 0.346 ano.350, respectively.

These findings are consistent with those of Demirguc-Kunt, Beck, and Honohan (2008) and Boukhatem (2016) who emphasized the importance of financial access in reducing poverty in addition to financial development through increasing the money supply or bank credit, which contributes to improving the welfare of the poor. Financial development also facilitates and increases financial transactions, improving asset accumulation and smoothing consumption.

The insignificant effect of $A T M$ and $B R C H$ under most estimation methods may be explained by weak financial institutional structures; thus, only by developing the banking sector and integrating elements of financial inclusion within a stronger framework will a positive impact on poverty be realized (Cumming and Uzuegbunam (2016); Neaime and Gaysset (2018)).

Finally, the most influential control variables on poverty are Trade and Infl. Showing a significantly negative effect under four estimation methods, strengthening trade is one way of reducing poverty, whereas the significantly positive effect under seven estimation methods means inflation must be controlled if it is not to increase poverty.

The results in Table 3 indicate a negative impact of financial inclusion on income inequality under all estimation methods, though the most significant effects at the $1 \%$ and $5 \%$ level are exerted by $B R C H$ and $B R W$. On average, income inequality can be alleviated by 0.05 and 0.058 under Diff and Sys, respectively, for each $1 \%$ rise in the bank penetration rate, while a $1 \%$ rise in credit can reduce income inequality by 0.032 and 0.038 , respectively. It may therefore be inferred that the higher the bank penetration rate, or the greater the availability of credit, the easier the poor can access financial services, which, as proxies for financial inclusion, enables the poor to be integrated into the financial system and income inequality reduced. This is reinforced by the results under C.FE at the same significance levels: on average, income inequality is reduced by 0.089 and 0.041 for each $1 \%$ rise in the bank penetration rate and credit, respectively.

Similar findings are reported by Neaime and Gaysset (2018) who found a negative and significant relationship, at $1 \%$ significance, between financial inclusion (i.e., using $B R C H$ as the proxy variable) and the GINI coefficient, which means the gap between rich and poor is reduced.

The control variables exerting a significant effect on income inequality are Expense and Trade. As the impact of government spending is positive, it suggests that government policy does not aim at reducing income inequality, either directly or indirectly; rather it accentuates it. In contrast, as trade exerts a significantly negative effect under three estimation methods, significantly positive under two, and no significant effect under the remainder, its impact is ambiguous. 
Asian Economic and Financial Review, 2020, 10(9): 1051-1061

Table-2. Estimation results for effect of financial inclusion on poverty.

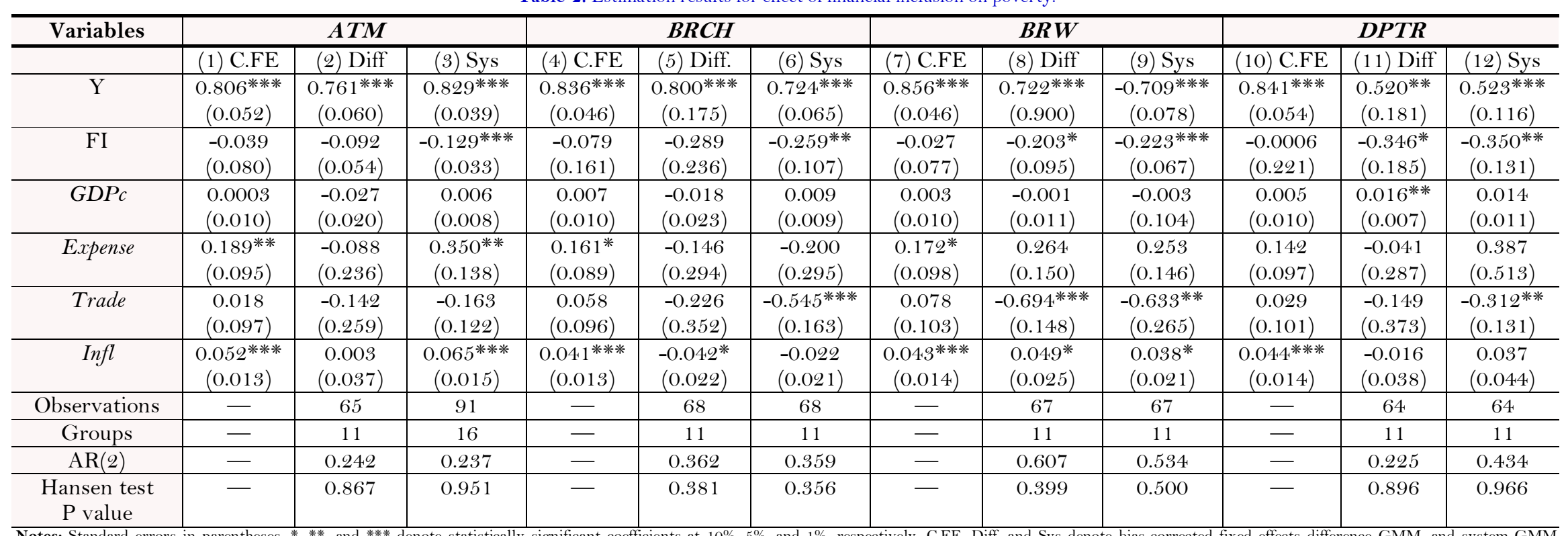

Notes: Standard errors in parentheses. * **, and ${ }^{* * *}$ denote statistically significant coefficients at $10 \%, 5 \%$, and $1 \%$, respectively. C.FE, Diff, and Sys denote bias-corrected fixed effects difference GMM, and system GMM estimation, respectively. FI denotes financial inclusion. $\operatorname{AR}(2)$ denotes Arellano-Bond test for second-order serial correlation. 


\begin{tabular}{|c|c|c|c|c|c|c|c|c|c|c|c|c|}
\hline \multirow[t]{2}{*}{ Variables } & \multicolumn{3}{|c|}{$A T M$} & \multicolumn{3}{|c|}{$\mathrm{BRCH}$} & \multicolumn{3}{|c|}{$B R W$} & \multicolumn{3}{|c|}{ DPTR } \\
\hline & (1) C.FE & (2) Diff & (3) Sys & (4) C.FE & (5) Diff & (6) Sys & (7) C.FE & (8) Diff & (9) Sys & (10) C.FE & (11) Diff & (12) Sys \\
\hline $\mathrm{Y}$ & $\begin{array}{c}0.685^{* * * *} \\
(0.076) \\
\end{array}$ & $\begin{array}{c}0.449^{* *} \\
(0.177) \\
\end{array}$ & $\begin{array}{c}0.572^{* * * *} \\
(0.093) \\
\end{array}$ & $\begin{array}{c}1.012^{* * * *} \\
(0.047)\end{array}$ & $\begin{array}{c}0.966^{* * * *} \\
(0.042)\end{array}$ & $\begin{array}{c}1.037^{* * * *} \\
(0.068) \\
\end{array}$ & $\begin{array}{c}0.820^{* * * *} \\
(0.114)\end{array}$ & $\begin{array}{c}0.8233^{* * * *} \\
(0.113)\end{array}$ & $\begin{array}{c}0.903 * * * \\
(0.076)\end{array}$ & $\begin{array}{c}0.741 * * * \\
(0.077)\end{array}$ & $\begin{array}{c}0.934^{* * * *} \\
(0.128) \\
\end{array}$ & $\begin{array}{c}0.933 * * * \\
(0.130) \\
\end{array}$ \\
\hline FI & $\begin{array}{l}-0.002 \\
(0.295)\end{array}$ & $\begin{array}{l}-0.041 \\
(0.037) \\
\end{array}$ & $\begin{array}{c}-0.050^{*} \\
(0.024)\end{array}$ & $\begin{array}{c}-0.089^{* * *} \\
(0.032)\end{array}$ & $\begin{array}{c}-0.050^{* * *} \\
(0.022)\end{array}$ & $\begin{array}{c}-0.058^{* * *} \\
(0.026)\end{array}$ & $\begin{array}{c}-0.0411^{* * * *} \\
(0.012)\end{array}$ & $\begin{array}{c}-0.032^{* * * *} \\
(0.010)\end{array}$ & $\begin{array}{c}-0.038^{* * * *} \\
(0.012)\end{array}$ & $\begin{array}{l}-0.018 \\
(0.012)\end{array}$ & $\begin{array}{c}-0.022^{*} \\
(0.011)\end{array}$ & $\begin{array}{l}-0.025^{*} \\
(0.011)\end{array}$ \\
\hline$G D P c$ & $\begin{array}{c}0.004 \\
(0.004) \\
\end{array}$ & $\begin{array}{c}0.008^{* * * *} \\
(0.002)\end{array}$ & $\begin{array}{l}-0.004 \\
(0.004)\end{array}$ & $\begin{array}{l}0.005^{*} \\
(0.002) \\
\end{array}$ & $\begin{array}{c}0.003 \\
(0.003) \\
\end{array}$ & $\begin{array}{c}-0.00003 \\
(0.009)\end{array}$ & $\begin{array}{l}0.0002 \\
(0.007)\end{array}$ & $\begin{array}{c}0.003 \\
(0.007) \\
\end{array}$ & $\begin{array}{l}0.0001 \\
(0.007)\end{array}$ & $\begin{array}{c}0.006 \\
(0.003)\end{array}$ & $\begin{array}{l}-0.006 \\
(0.007)\end{array}$ & $\begin{array}{l}-0.003 \\
(0.007)\end{array}$ \\
\hline Expense & $\begin{array}{c}0.067 \\
(0.041)\end{array}$ & $\begin{array}{c}0.088 \\
(0.149) \\
\end{array}$ & $\begin{array}{c}0.028 \\
(0.076)\end{array}$ & $\begin{array}{c}0.198^{* * * *} \\
(0.057)\end{array}$ & $\begin{array}{c}0.127 * * \\
(0.047)\end{array}$ & $\begin{array}{l}0.124^{*} \\
(0.065)\end{array}$ & $\begin{array}{c}0.074 * * * \\
(0.024)\end{array}$ & $\begin{array}{c}0.063^{* *} \\
(0.025) \\
\end{array}$ & $\begin{array}{c}0.063 * * \\
(0.028)\end{array}$ & $\begin{array}{l}0.074^{*} \\
(0.042)\end{array}$ & $\begin{array}{c}0.058 \\
(0.044)\end{array}$ & $\begin{array}{l}0.089^{*} \\
(0.048)\end{array}$ \\
\hline Trade & $\begin{array}{c}0.085^{* *} \\
(0.037)\end{array}$ & $\begin{array}{l}-0.142^{*} \\
(0.067)\end{array}$ & $\begin{array}{l}-0.084 * \\
(0.044)\end{array}$ & $\begin{array}{c}0.123 \\
(0.081)\end{array}$ & $\begin{array}{l}-0.036 \\
(0.033)\end{array}$ & $\begin{array}{c}0.044 \\
(0.039)\end{array}$ & $\begin{array}{l}-0.085 \\
(0.059)\end{array}$ & $\begin{array}{c}-0.089^{* *} * \\
(0.041)\end{array}$ & $\begin{array}{l}-0.061 \\
(0.060)\end{array}$ & $\begin{array}{l}0.075^{*} \\
(0.039)\end{array}$ & $\begin{array}{l}-0.065 \\
(0.051)\end{array}$ & $\begin{array}{l}-0.044 \\
(0.052)\end{array}$ \\
\hline Infl & $\begin{array}{c}0.006 \\
(0.005)\end{array}$ & $\begin{array}{l}-0.001 \\
(0.008)\end{array}$ & $\begin{array}{l}-0.016^{*} \\
(0.008)\end{array}$ & $\begin{array}{l}-0.010 \\
(0.012)\end{array}$ & $\begin{array}{c}0.011 \\
(0.008)\end{array}$ & $\begin{array}{l}-0.006 \\
(0.008)\end{array}$ & $\begin{array}{l}-0.003 \\
(0.009)\end{array}$ & $\begin{array}{l}-0.003 \\
(0.002)\end{array}$ & $\begin{array}{l}-0.009 \\
(0.007)\end{array}$ & $\begin{array}{c}0.004 \\
(0.005)\end{array}$ & $\begin{array}{c}0.006 \\
(0.004)\end{array}$ & $\begin{array}{c}0.003 \\
(0.005)\end{array}$ \\
\hline Observations & - & 72 & 100 & - & 105 & 105 & - & 99 & 99 & - & 97 & 97 \\
\hline Groups & - & 13 & 16 & - & 16 & 16 & - & 16 & 16 & - & 15 & 15 \\
\hline $\operatorname{AR}(2)$ & - & 0.183 & 0.189 & - & 0.161 & 0.117 & - & 0.129 & 0.124 & - & 0.174 & 0.107 \\
\hline $\begin{array}{c}\text { Hansen test } \\
\mathrm{P} \text { value }\end{array}$ & - & 0.319 & 0.925 & - & 0.617 & 0.817 & - & 0.938 & 0.961 & - & 0.348 & 0.615 \\
\hline
\end{tabular}

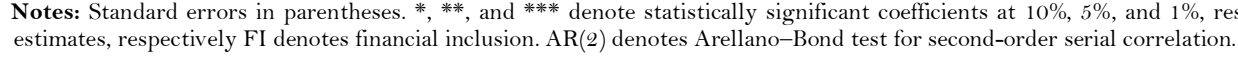


A comparison of the results from Tables 2 and 3 reveals the effect of financial inclusion on income inequality is more robust. C.FE estimation results in negative and significant impacts in Table 3, which reinforces the results from both Diff and Sys estimation; however, C.FE shows no significant impacts in Table 2. Thus, C.FE serves as a robust instrument to reinforce the significantly negative relationship between financial inclusion and income inequality.

\section{CONCLUSION}

The results of the different dynamic panel data estimators-bias-corrected fixed effects, difference GMM, and system GMM - highlight the negative relationship between financial inclusion and income inequality. In the main, the two proxy variables for financial inclusion, $B R C H$ and $B R W$, exert significant effects on income inequality, at both the $1 \%$ and $5 \%$ levels of significance. Further, C.FE served as robust instrument, confirming the significantly negative impact of financial inclusion on income inequality. Thus, the bank penetration rate and availability of credit enable the poor to be integrated into the financial system, reducing income inequality. As such, the findings of the current study are consistent with those of Neaime and Gaysset (2018).

With regard to the impact of financial inclusion on poverty, the two proxy variables, BRW and DPTR, exert significantly negative effects, confirming the results of Demirguc-Kunt et al. (2008) and Boukhatem (2016). These authors also stated that financial development can reduce poverty by increasing the money supply or credit available, which will contribute to improving the welfare of the poor.

Evidence for the benefits of financial development should encourage policymakers to develop a greater number of more inclusive financial institutions by implementing reforms that not only facilitate financial access but also improve banking services and the efficiency of credit institutions.

In addition, it is recommended that appropriate policies are implemented to improve household incomes, participation in the financial system, and access to information to minimize financial exclusion; such policies include wider dissemination of financial literature in rural and marginalized areas to raise public awareness of financial services. Moreover, encouraging innovative financial tools and improving financial inclusion to reduce poverty and income inequality should be prioritized to facilitate the integration of marginalized people into the banking and financial system. This study also supports the idea that effective trade policies can contribute to poverty reduction and improve the financial fragility of individuals in developing countries.

Funding: This study received no specific financial support.

Competing Interests: The author declares that there are no conflicts of interests regarding the publication of this paper.

\section{REFERENCES}

Agyemang-Badu, A. A., Agyei, K., \& Kwaku Duah, E. (2018). Financial inclusion, poverty and income inequality: Evidence from Africa. Spiritan International Journal of Poverty Studies, 2(2), 1-19.

Allen, F., Demirguc-Kunt, A., Klapper, L., \& Peria, M. S. M. (2016). The foundations of financial inclusion: Understanding ownership and use of formal accounts. Journal of Financial Intermediation, 27(C), 1-30. Available at: https://doi.org/10.1016/j.jfi.2015.12.003.

Arellano, M., \& Bond, S. (1991). Some tests of specification for panel data: Monte Carlo evidence and an application to employment equations. The Review of Economic Studies, 58(2), 277-297. Available at: https://doi.org/10.2307/2297968

Blundell, R., \& Bond, S. (1998). Initial conditions and moment restrictions in dynamic panel data models. Journal of Econometrics, 87(1), 115-143. Available at: https://doi.org/10.1016/s0304-4076(98)00009-8.

Boukhatem, J. (2016). Assessing the direct effect of financial development on poverty reduction in a panel of low-and middleincome countries. Research in International Business and Finance, 37, 214-230. Available at: https://doi.org/10.1016/j.ribaf.2015.11.008. 
Brune, L., Giné, X., Goldberg, J., \& Yang, D. (2011). Commitments to save: A field experiment in rural Malawi. World Bank Policy Research Working Paper No. 5748.

Bun, M. J., \& Kiviet, J. F. (2003). On the diminishing returns of higher-order terms in asymptotic expansions of bias. economics Letters, 79(2), 145-152. Available at: https://doi.org/10.1016/s0165-1765(02)00299-9.

Chauvet, L., \& Jacolin, L. (2017). Financial inclusion, bank concentration, and firm performance. World Development, 97, 1-13. Available at: https://doi.org/10.1016/j.worlddev.2017.03.018.

Claessens, S. (2006). Access to financial services: A review of the issues and public policy objectives. The World Bank Research Observer, 21(2), 207-240. Available at: https://doi.org/10.1093/wbro/lklo04.

Collard, S. (2010). Toward financial inclusion in the UK: Progress and challenges. Public Money and Management, 27(1), 13-20.

Cumming, D., Johan, S., \& Zhang, M. (2014). The economic impact of entrepreneurship: Comparing international datasets. Corporate Governance: An International Review, 22(2), 162-178. Available at: https://doi.org/10.1111/corg. 12058.

Cumming, D., \& Uzuegbunam, U. (2016). Inequality, entrepreneurial activity and poverty alleviation. Paper presented at the SMS Conference, Berlin.

Demirguc-Kunt, A., Beck, T., \& Honohan, P. (2008). Finance for all: Policies and pitfalls in expanding access (pp. 259-267): World Bank Publications.

Demirguc-Kunt, A., \& Klapper, L. (2012). Measuring financial inclusion: The global findex database. World Bank Policy Research Working Paper No. 6025.

Demirgüç-Kunt, A., Klapper, L. F., \& Singer, D. (2013). Financial inclusion and legal discrimination against women: Evidence from developing countries. World Bank Policy Research Working Paper.

Demirgüc,-Kunt, A., \& Klapper, L. (2012b). Financial inclusion in Africa: An overview. World Bank Policy Research Working Paper, No. 6088. Washington, DC: World Bank.

Evans, O., \& Adeoye, B. (2016). Determinants of financial inclusion in Africa: A dynamic panel data approach. University of Mauritius Research Journal, 22(2016), 310-336.

Han, R., \& Melecky, M. (2013). Financial inclusion for financial stability: Access to bank deposits and the growth of deposits in the global financial crisis. World Bank Policy Research Working Paper No. 6577. Washington, DC: World Bank.

Honohan, P. (2004). Financial development, growth and poverty: How close are the links. In Charles Goodhart (Ed.), Financial Development and Economic Growth: Explaining the Links. London, UK: Palgrave.

Jabir, I. M., Mensah, L., \& Gyeke-Dako, A. (2017). Financial inclusion and poverty reduction in Sub-Saharan Africa. African Finance Journal, 19(1), 1-22.

Kim, J.-H. (2016). A study on the effect of financial inclusion on the relationship between income inequality and economic growth. Emerging Markets Finance and Trade, 52(2), 498-512.

Kim, D.-W., Yu, J.-S., \& Hassan, M. K. (2018). Financial inclusion and economic growth in OIC countries. Research in International Business and Finance, 43(C), 1-14.

Kostov, P., Arun, T., \& Annim, S. (2015). Access to financial services: The case of the 'Mzansi'account in South Africa. Review of Development Finance, 5(1), 34-42.

Le, T.-H., Chuc, A. T., \& Taghizadeh-Hesary, F. (2019). Financial inclusion and its impact on financial efficiency and sustainability: Empirical evidence from Asia. Borsa Istanbul Revierw, 19(4), 310-322. Available at: https://doi.org/10.1016/j.bir.2019.07.002.

Leyshon, A., \& Thrift, N. (1995). Geographies of financial exclusion: financial abandonment in Britain and the United States. Transactions-Institute of British Geographers (1965), 20(3), 312-341.

Neaime, S., \& Gaysset, I. (2018). Financial inclusion and stability in MENA: Evidence from poverty and inequality. Finance Research Letters, 24, 230-237. Available at: https://doi.org/10.1016/j.frl.2017.09.007.

Omar, M. A., \& Inaba, K. (2020). Does financial inclusion reduce poverty and income inequality in developing countries? A panel data analysis. Journal of Economic Structures, 9(1), 1-25. Available at: https://doi.org/10.1 186/s40008-020-002 14-4. 
Park, C., \& Mercado, R. V. (2015). Financial inclusion, poverty, and income inequality in developing Asia. ADB Economics Working Paper Series No. 426/2015. Manila, Philippines.

Pearce, D. (2011). Financial inclusion in the Middle East \& North Africa: Analysis and roadmap recommendations. World Bank Policy Research Working Papers Series No. (5610).

Rangarajan, C. (2008). Report of the committee on financial inclusion: Ministry of Finance, Government of India.

Rizwan, M., \& Bruneau, C. (2019). Microfinance, financial inclusion and ICT: Implications for poverty and inequality. Technology in Society, 59, 101154.

Rojas-Suarez, L., \& Amado, M. A. (2014). Understanding Latin America's financial inclusion gap. Center for Global Development Working Paper No. 367. Washington, DC.

Sarma, M., \& Pais, J. (201 1). Financial inclusion and development. Journal of International Development, 23(5), 613-628.

Sinclair, S. P. (2001). Financial exclusion: An introductory survey: CRSIS: Edinburgh College of Art/Heriot Watt University.

Swamy, V. (2014). Financial inclusion, gender dimension, and economic impact on poor households. World Development, 56, 1-15. Available at: https://doi.org/10.1016/j.worlddev.2013.10.019.

World Bank. (2019). Global financial development report. Washington DC: World Bank.

Zins, A., \& Weill, L. (2016). The determinants of financial inclusion in Africa. Review of Development Finance, 6(1), 46-57. Available at: https://doi.org/10.1016/j.rdf.2016.05.001.

Views and opinions expressed in this article are the views and opinions of the author(s), Asian Economic and Financial Review shall not be responsible or answerable for any loss, damage or liability etc. caused in relation to/arising out of the use of the content. 